\section{$\cap \wedge \quad$\begin{tabular}{l|l} 
DIRECTORY OF \\
OPEN ACCESS
\end{tabular} \\ JOURNALS}

P-ISSN: 2548-5962

https://ojs.unud.ac.id/index.php/jbn
E-ISSN: 2548-981X

REVIEW ARTICLE

Peran Poly-(ADP ribose) polymerase (PARP) dan Phosphatidylinositol 3-kinase (PI3K) Terhadap Terjadinya Kejadian Metastasis pada Kanker Payudara

\author{
I Wayan Gede Suarsana ${ }^{1 *}$, Andi Asadul Islam² ${ }^{2}$ Prihantono $^{1}$, Berti Julian Nelwan ${ }^{3}$ \\ ${ }^{1}$ Departemen Bedah Onkologi, Fakultas Kedokteran, Universitas Hasanuddin, Makassar, 90245, Indonesia. \\ ${ }^{2}$ Departemen Bedah Saraf, Fakultas Kedokteran, Universitas Hasanuddin, Makassar, 90245, Indonesia. \\ ${ }^{3}$ Departemen Patologi Anatomi, Fakultas Kedokteran, Universitas Hasanuddin, Makassar, 90245, Indonesia.
}

*Penulis korespondensi: iwgsuarsana21@gmail.com

\title{
ABSTRAK
}

Kanker payudara merupakan penyebab kematian akibat kanker terbanyak pada wanita di seluruh dunia dengan angka kematian sebesar 458.400 wanita setiap tahunnya. Poly-(ADP ribose) polymerase (PARP) dan phosphatidylinositol 3-kinase (PI3K) adalah dua molekul yang memainkan peran penting pada patofisiologi kanker payudara. Metastasis kanker payudara merupakan sebuah proses berkesinambungan yang melibatkan beberapa tahapan penting seperti invasi, angiogenesis, hingga replikasi sel. Sel yang mengalami mutasi pada kanker payudara akan menyebabkan ekspresi yang berlebihan dari PI3K sehingga terjadi replikasi sel yang tidak terkontrol disertai dengan peningkatan matrix metallopeptidase 9 (MMP-9). MMP-9 memiliki peran dalam degradasi matriks ekstraseluler yang penting untuk proses invasi tumor. Di sisi lain, PARP membantu reparasi sel yang mengalami kerusakan sehingga proses replikasi sel kanker dapat terus berlangsung. Terlebih lagi, PARP diketahui memiliki andil besar dalam proses angiogenesis sel kanker. Gabungan dari kedua fenomena tersebut menghasilkan sel kanker dengan kemampuan replikasi dan metastasis yang tinggi.

Kata kunci: Kanker payudara, PARP, PI3K, metastasis, AKT.

DOI: https://doi.org/10.24843/JBN.2022.v06.i01.p05

\section{ABSTRACT}

Breast cancer is the leading cause of cancer death in women worldwide, with a death rate of 458,400 women each year. Poly-(ADP ribose) polymerase (PARP) and phosphatidylinositol 3-kinase (PI3K) are two molecules that play an essential role in the pathophysiology of breast cancer. Metastasis in breast cancer is a process that involves several necessary steps, such as invasion, angiogenesis, and cell replication. Mutated cells in breast cancer will cause excessive production of PI3K, causing uncontrolled cell replication accompanied by an increase in matrix metallopeptidase 9 (MMP-9). MMP9 has a role in the degradation of the extracellular matrix, which is vital for tumour invasion. On the other hand, PARP helps repair damaged cells to replicate cancer cells continuously. Moreover, PARP is known to have a significant role in the angiogenesis process of cancer cells. Combining these two phenomena produces cancer cells with high replicative and metastatic capabilities.

Keywords: Breast cancer, PARP, PI3K, metastasis, AKT.

\section{PENDAHULUAN}

Kanker payudara merupakan kanker yang paling sering didiagnosis dan menjadi penyebab kematian akibat kanker terbanyak pada wanita di seluruh dunia. Pada tahun 2011, angka kejadian kanker payudara di dunia berkisar 1.380.000 kasus baru per tahun atau sekitar $14 \%$ dari seluruh kanker yang diperiksa setiap tahunnya dan kematian akibat kanker payudara berkisar 458.400 pada wanita. Secara keseluruhan, kanker payudara adalah penyebab kematian terbanyak kedua setelah kanker paru. ${ }^{1}$ 
Beberapa faktor risiko dari kanker payudara meliputi riwayat keluarga, usia, perubahan hormonal, hingga pola hidup yang diasosiasikan dengan eksposur karsinogen. ${ }^{2}$ Sebagian kecil pasien dengan kanker payudara mewarisi mutasi germinal pada DNA yang sering kali berakibat pada hilangnya fungsi gen yang terlibat dalam perbaikan DNA dan mekanisme siklus sel. Kerusakan yang terjadi pada dua gen yang penting, yaitu BRCA1 dan BRCA2, dapat menyebabkan peningkatan risiko kanker payudara hingga $70 \%$ lebih tinggi dibandingkan populasi umum. Selain itu, mutasi tersebut juga meningkatkan risiko kanker ovarium hingga $15-40 \%{ }^{3}$

Salah satu perkembangan yang paling penting sejak diketahuinya relasi antara mutasi germinal gen BRCA dengan kanker payudara ataupun ovarium adalah identifikasi molekul poly-(ADP ribose) polymerase (PARP) dan phosphatidylinositol 3-kinase (PI3K). Kedua molekul tersebut diketahui memiliki peranan penting dalam patofisiologi kanker payudara seperti metastasis tumor. ${ }^{2-4}$ Mengetahui bagaimana kedua molekul tersebut berinteraksi dengan sel tumor serta mekanismenya menjadi kunci yang penting dalam mengembangkan terapi yang tepat untuk kanker payudara.

Pada tulisan ini, penulis akan menyajikan secara singkat mekanisme serta peran PARP dan PI3K terhadap terjadinya kejadian metastasis pada pasien dengan kanker payudara.

\section{Metastasis pada Kanker Payudara}

Pada keadaan normal, sel akan berada dalam organ yang tepat dan tidak dapat berpindah dari satu organ ke organ lainnnya. Situasi ini dapat berubah pada proses keganasan dan sel-sel yang mengalami keganasan akan memiliki kemampuan untuk bergerak dan tumbuh di organ lain. Sifat unik dan berpotensi berbahaya dari sel kanker inilah yang dinamakan dengan metastasis. Metastasis dapat terjadi melalui tiga jalur, yaitu invasi lokal ke jaringan sekitar, metastasis sistemik ke organ jauh melalui darah, dan metastasis limfatik melalui pembuluh limfatik (kelenjar getah bening sentinel, kelenjar getah bening distal, dan organ distal).

Stricker, dkk menggambarkan metastasis pada sel kanker melalui darah sebagai suatu proses yang berkesinambungan, yaitu sebagai berikut: ${ }^{5}$ (1) invasi yaitu sel tumor tumbuh melalui lapisan membrana basalis dan menginvasi ke matriks ekstraseluler. Proses invasi diawali dengan meregangnya sel tumor dan perlekatan sel tumor ke berbagai protein matriks ekstraseluler. Kemudian, ada kerusakan lokal membran basal dan jaringan ikat interstitium yang memungkinkan sel tumor dapat bermigrasi melalui membran basalis. (2) intravasasi: dari matriks ekstraseluler, sel tumor menginvasi endotel vaskular dan mulai menyebar ke dalam aliran darah tersebut. (3) sirkulasi: dalam aliran darah, beberapa sel tumor membentuk emboli (trombus) yang kemudian menempel pada sel darah putih dan trombosit. (4) ekstravasasi: setelah mencapai lokasi organ yang akan diinangi, sel tumor atau emboli menempel pada endotel vaskular dan kemudian bergerak melintasi membran basal dengan mekanisme yang mirip dengan invasi. (5) angiogenesis: ketika sel tumor tiba di organ inang, mereka mengeluarkan faktor pertumbuhan dan merangsang pembentukan pembuluh darah baru. (6) pertumbuhan: setelah semua fasilitas cukup untuk menopang kehidupan sel tumor, sel tumor tumbuh dan membelah dan mulai membentuk tumor baru.

Metastasis melalui pembuluh limfatik ke kelenjar getah bening digunakan untuk menentukan stadium serta prognosis yang berfungsi sebagai panduan untuk perencanaan pengobatan. Namun, mekanisme molekuler 
yang menyebabkan metastasis ke kelenjar getah bening sentinel dan kelenjar getah bening distal tidak dipahami dengan jelas. Di masa lalu, dikatakan bahwa sel tumor diangkut secara pasif dari pembuluh limfatik karena permeabilitas pembuluh darah limfatik lebih tinggi jika dibandingkan dengan pembuluh darah biasa dengan membran basalisis. Studi tentang peran sistem limfatik dalam metastasis kanker telah terhambat oleh kurangnya penanda spesifik yang membedakan pembuluh limfatik dari pembuluh darah dan kurangnya faktor spesifik untuk pertumbuhan limfatik yang diketahui. ${ }^{6-8}$

Terlepas dari berbagai jalur metastasis tersebut, sifat sel kanker yang krusial dalam keberhasilan proses metastasis adalah kemampuannya dalam bertahan hidup, reparasinya. bereplikasi dan tumbuh secara tidak PI3K.

terkontrol. Beberapa molekul yang telah diketahui memiliki peranan tersebut dan telah diteliti secara ekstensif adalah PARP dan

\section{PARP dan metastasis sel kanker}

PARP merupakan sekelompok enzim (PARP1 dan PARP2) yang berperan dalam mekanisme reparasi DNA. ${ }^{9,10}$ Struktur PARP terdiri dari sebuah $N$-terminal double zinc finger, DNA binding domain (DBD), nuclear localization signal, central automodification domain, dan C-terminal catalytic domain. Secara garis besar, terdapat lima macam mekanisme reparasi DNA sesuai dengan jenis kerusakannya. ${ }^{11}$ Gambar $\mathbf{1}$ menunjukkan enis kerusakan DNA serta mekanisme

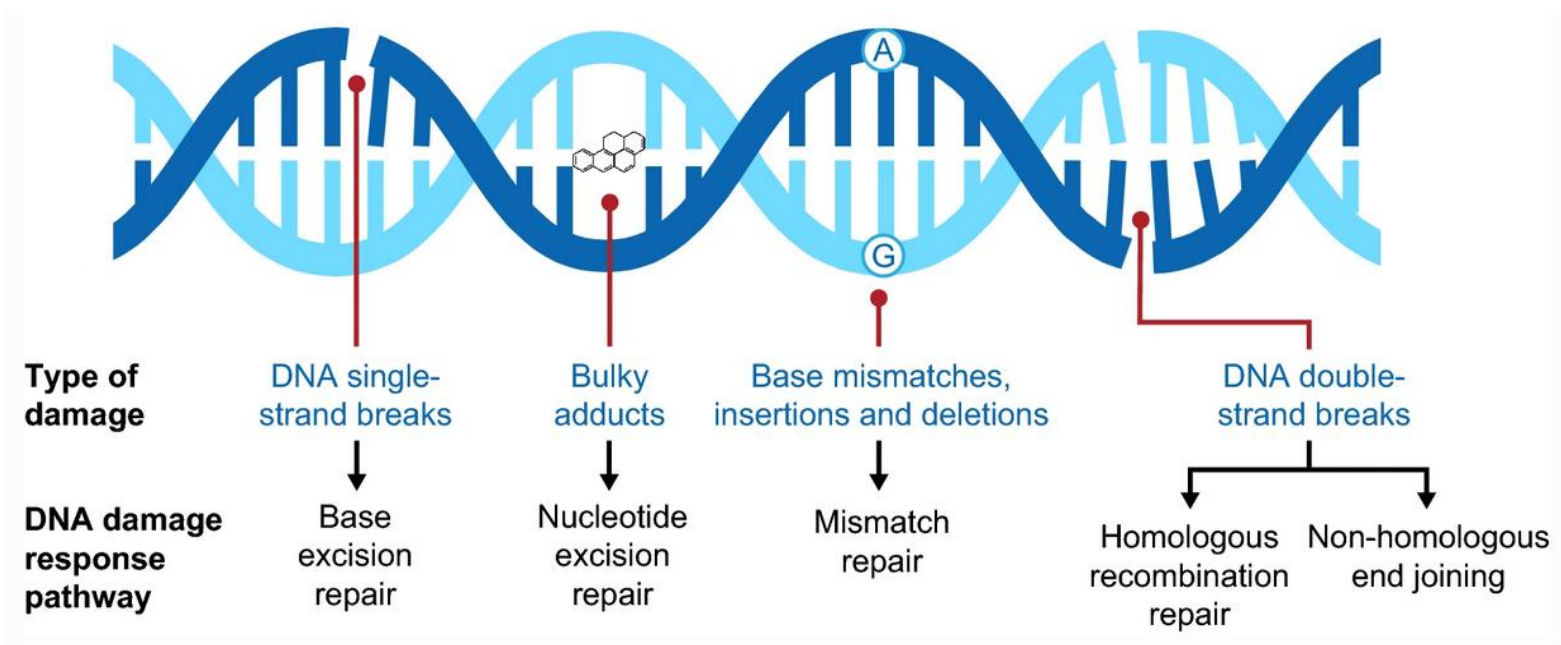

Gambar 1. Jenis kerusakan DNA serta mekanisme reparasinya ${ }^{8}$

Mekanisme reparasi DNA utama pada single strand breaks (SSB) diperantarai oleh PARP melalui base excision repair (BER) sedangkan untuk double strand breaks (DSB) diperantarai oleh BRCA melalui homologous recombination (HR). ${ }^{12-14}$ Apabila terjadi kerusakan DNA, PARP1 akan mengalami aktivasi dan memicu terjadinya sintesis polimer. Setelah teraktivasi, maka PARP1 akan menginisiasi modifikasi sejumlah protein yang terbentuk akan didegradasi oleh poly (histon, p53, Ataxia Telangiectasia Mutated, protein base excision repair, dan faktor-faktor transkripsi) serta melakukan automodifikasi. ${ }^{11}$ Automodifikasi PARP1 akan menyebabkan protein ini menjadi tidak aktif dan kehilangan afinitasnya terhadap DNA, sehingga memungkinkan kompleks polimer untuk mereparasi DNA. Setelah proses reparasi DNA selesai, maka kompleks polimer 
(ADP-ribose) glycohydrolase (PARG) reparasi DNA $^{9}$ Gambar 2 merupakan sehingga PARP1 dapat melanjutkan siklus mekanisme aktivasi dan regulasi PARP1.

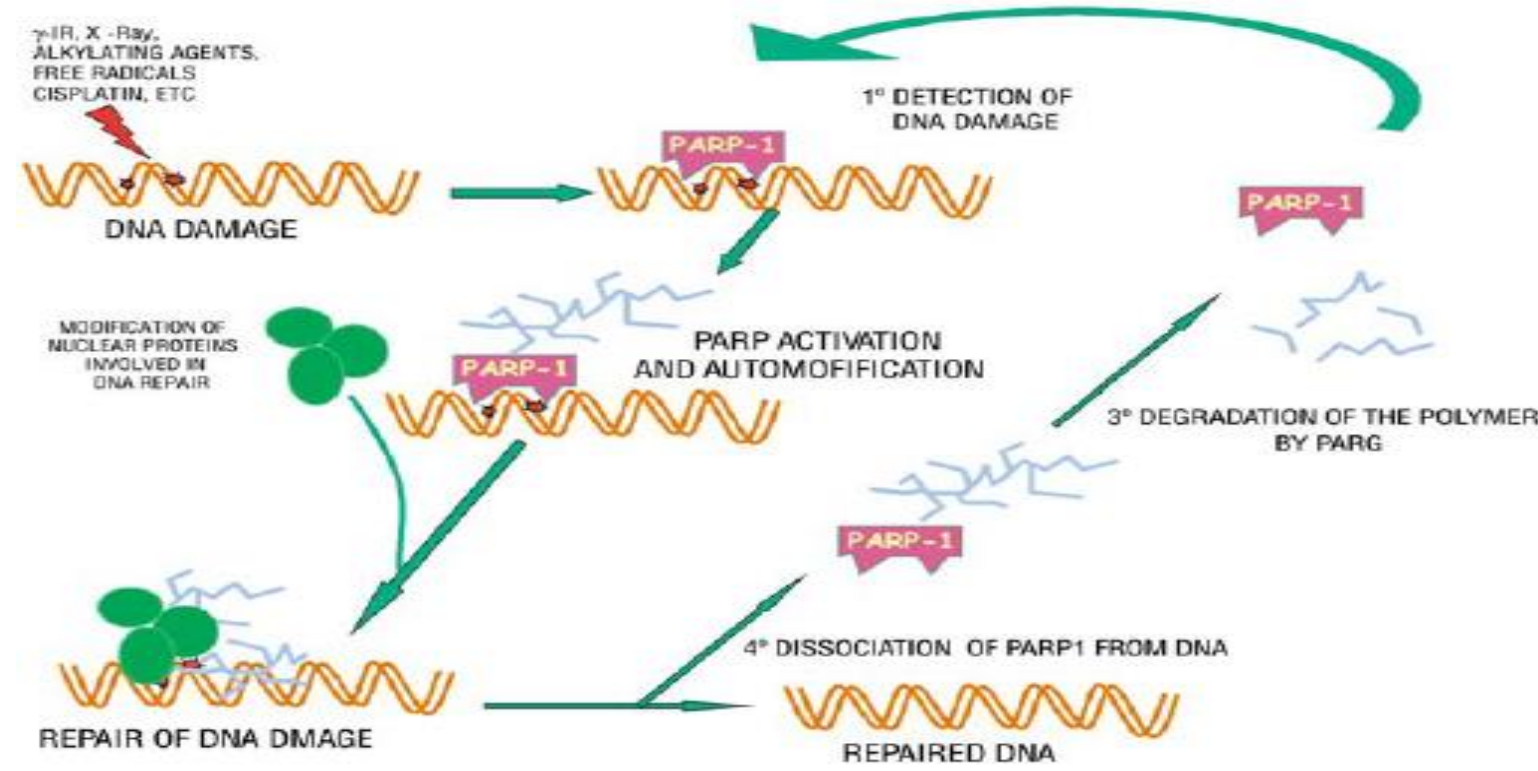

Gambar 2. Mekanisme aktivasi dan regulasi PARP1 ${ }^{2}$

Proses replikasi dan reparasi SSB oleh PARP1 merupakan komponen yang penting untuk kelangsungan hidup sel kanker. SSB yang tidak direparasi lambat laun akan berakumulasi dan mengalami degradasi menjadi DSB yang bersifat sitotoksik. Namun, sel kanker dengan mutasi BRCA1 dan BRCA2 kehilangan kemampuan untuk melakukan reparasi DSB yang seharusnya diperantarai oleh mekanisme HR. Oleh karena itu, pertumbuhan hingga metastasis sel kanker sangat bergantung pada peranan PARP1. ${ }^{15}$

Selain itu, PARP1 juga diduga memiliki peran dalam proses angiogenesis tumor. Analisis microarray complementary DNA (mcDNA) pada karsinogenesis kulit menunjukkan bahwa PARP1 memodulasi ekspresi gen-gen yang berperan dalam angiogenesis, seperti HIF1- $\alpha$, Pecam-1 dan OPN. ${ }^{16}$ Secara khusus, inhibisi aktivitas PARP1 ternyata menurunkan aktivitas hypoxia inducible factor. Hypoxia inducible factor berperan dalam regulasi adaptasi sel tumor dalam keadaan hipoksia melalui transaktivasi gen-gen yang berperan dalam transport glukosa, glikolisis, eritropoiesis, angiogenesis, vasodilasi, dan vascular endothelial growth factor (VEGF). ${ }^{17}$ Penurunan aktivitas HIFl- $\alpha$ pada tumor diduga dapat memicu terjadinya kematian sel tumor.

\section{PI3K dan metastasis sel kanker}

PI3K adalah bagian dari famili kinase lipid heterodimerik intraseluler yang berespon terhadap nutrisi, faktor pertumbuhan, dan berbagai sinyal dari lingkungan. PI3K juga memainkan peran penting dalam mengatur berbagai fungsi biologis seperti pertumbuhan sel, proliferasi, kelangsungan hidup, diferensiasi, metabolisme, motilitas, stabilitas genom, sintesis protein, hingga angiogenesis. ${ }^{4}$

Secara garis besar, PI3K dibagi menjadi tiga kelas (I-III) berdasarkan struktur dan sifat biokimianya. Dari ketiga kelas tersebut, PI3K kelas I diketahui berperan paling besar dalam proses onkogenesis. ${ }^{18}$ PI3K kelas 1 merupakan heterodimer yang terdiri dari sebuah subunit regulator p85 dan subunit

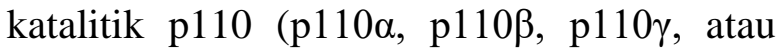


p1108). PI3K menerima sinyal aktivasi dari reseptor kinase tirosin (termasuk human epidermal growth factor receptor [HER], fibroblast growth factor receptor [FGFR], insulin-like growth factor-1 [IGF-1]) dan reseptor $G$ protein-coupled. PI3K yang teraktivasi selanjutnya akan memfosforilasi phosphatidylinositol

3,4,5-triphostphate (PIP3). Akumulasi dari PIP3 pada membran plasma akan merekrut protein kinase B (AKT) yang merupakan mediator utama dari jalur PI3K dan phosphoinositide-dependent kinase 1 (PDK1). ${ }^{4,18}$
Pada membran plasma, AKT akan difosforilasi oleh pyruvate dehydrogenase kinase-1 (PDK1) dan pyruvate dehydrogenase kinase-2 (PDK2) untuk mengalami aktivasi yang selanjutnya akan menstimulasi kaskade dibawahnya dengan mengaktivasikan mammalian target of rapamycin (mTOR) melalui efek dari perantara tuberous sclerosis complex 1/2 (TSC1/2). Protein phospatase and tensin homolog (PTEN) akan mengkatalisasi defosforilasi dari PIP3 menjadi PIP2 dan bertindak menjadi umpan balik negatif PI3K. ${ }^{4}$ Gambar 3 merupakan jalur sinyal PI3K.

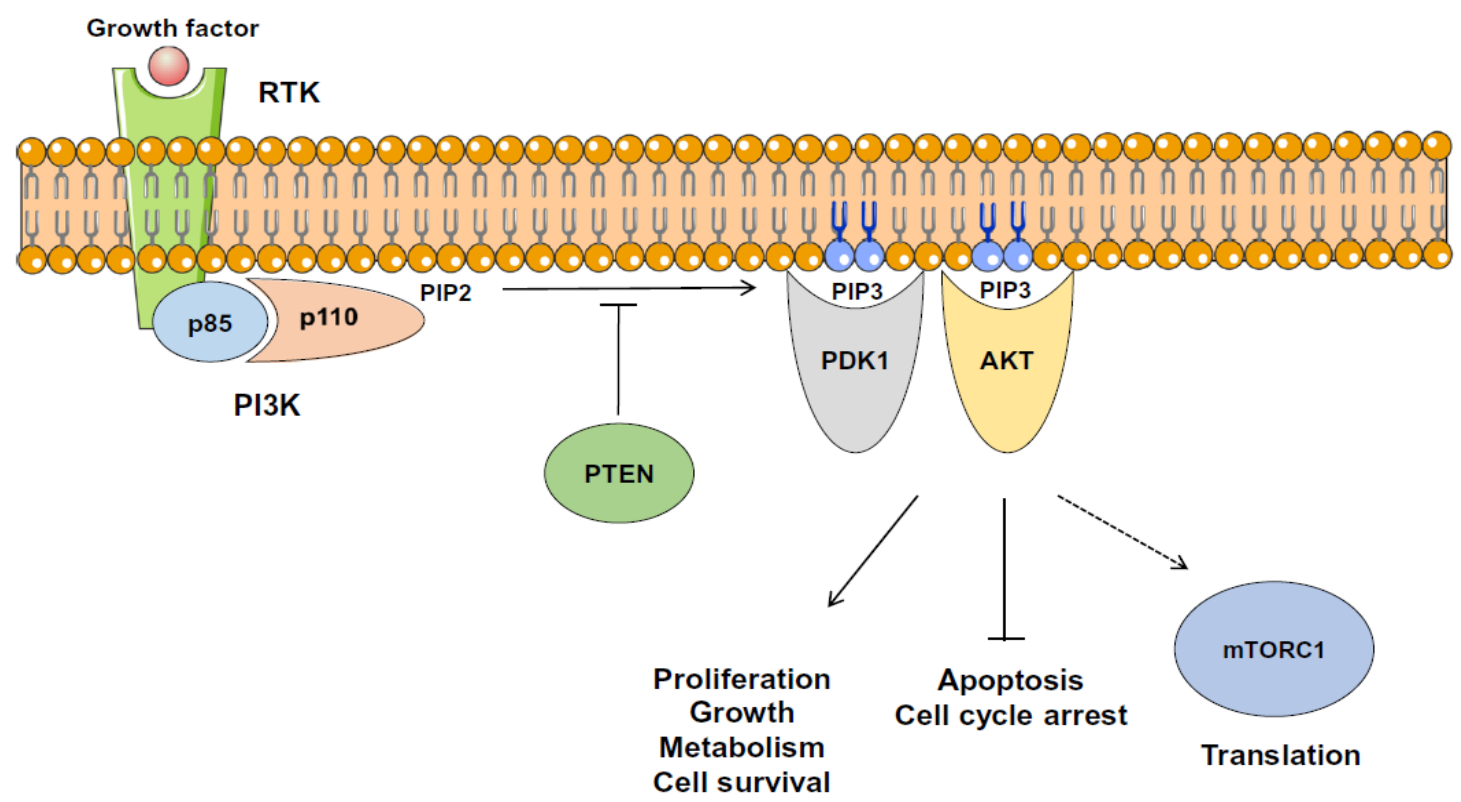

Gambar 3. Jalur sinyal PI3K ${ }^{4}$

Mutasi dari PIK3CA, gen yang mengkode salah satu subunit dari PI3K, adalah salah satu perubahan genomik yang paling umum terjadi. Mutasi tersebut paling umum terjadi pada kanker payudara dengan tipe luminal A (45\%), diikuti oleh tipe hormone receptor-positive (39\%), luminal B (30\%), dan triple negative breast cancer $(9 \%) .{ }^{19}$ Mayoritas dari mutasi tersebut terjadi pada domain heliks dan kinase sehingga terjadi aktivasi dari enzim PI3K yang selanjutnya menyebabkan fosforilasi yang berlebihan dari AKT beserta kaskade dibawahnya. $^{4,20}$ Hal tersebut menyebabkan matriks ekstraseluler, yaitu sebuah proses pertumbuhan sel secara tidak terkendali yang seringkali terlihat pada kanker payudara dan pada saat yang sama meningkatkan kemampuan sel kanker dalam metastasis. ${ }^{4}$

Studi lain oleh $\mathrm{Wu}$ dkk. mendapatkan bahwa ekspresi yang berlebihan dari PI3K pada kanker payudara juga akan meningkatkan membrane progesterone receptor alpha $(\mathrm{mPR} \alpha)$. Setelah itu, $\mathrm{mPR} \alpha$ akan meningkatkan ekspresi matrix metallopeptidase 9 (MMP-9). MMP-9 memainkan peranan penting dalam degradasi 
yang diperlukan dalam proses metastasis sel kanker. $^{21}$

\section{SIMPULAN}

PI3K dan PARP adalah dua komponen yang memainkan peran penting dalam proses fisiologis replikasi, pertumbuhan, serta kelangsungan hidup suatu sel normal. Pada pasien dengan kanker payudara, terjadi mutasi yang menyebabkan ekspresi berlebihan dari PI3K sehingga terjadi pertumbuhan sel yang tidak terkontrol. Di sisi lain, PARP membantu reparasi sel yang mengalami kerusakan sehingga proses replikasi sel kanker dapat terus berlangsung.

Fenomena tersebut menghasilkan sel kanker dengan kemampuan replikasi dan metastasis yang tinggi. Oleh karena itu, seyogyanya inhibisi yang bersamaan dari kedua molekul tersebut dapat menjadi fokus terapi kanker payudara yang menjanjikan untuk kedepannya.

\section{PERNYATAAN}

Tidak ada konflik kepentingan dalam karya tulis ini.

\section{DAFTAR PUSTAKA}

1. Jemal A, Bray F, Center MM, dkk. Global cancer statistics. CA Cancer $J$ Clin. 2011;61:69-90.

2. Cortesi L, Rugo HS, Jackisch C. An Overview of PARP Inhibitors for the Treatment of Breast Cancer. Target Oncol. 2021;16:255-82.

3. Zimmer AS, Gillard M, Lipkowitz S, dkk. Update on PARP Inhibitors in Breast Cancer. Curr Treat Options Oncol. 2018;19:1-19.

4. Ellis $\mathrm{H}, \mathrm{Ma}$ CX. PI3K Inhibitors in Breast Cancer Therapy. Curr Oncol Rep. 2019;21:110.

5. Kummar S, Wade JL, Oza AM, dkk. 15. Dziadkowiec KN, Gasiorowska E, Randomized phase II trial of Nowak-Markwitz E, dkk. PARP cyclophosphamide and the oral poly (ADP-ribose) polymerase inhibitor veliparib in patients with recurrent, advanced triple-negative breast cancer. Invest New Drugs. 2016;34:355-63.

6. Stacker SA, Williams SP, Karnezis T, dkk. Lymphangiogenesis and lymphatic vessel remodelling in cancer. Nat Rev Cancer. 2014;14:159-72.

7. Christiansen A, Detmar M. Lymphangiogenesis and cancer. Genes Cancer. 2011;2:1146-58.

8. Karaman S, Detmar M. Mechanisms of lymphatic metastasis. J Clin Invest. 2014;124:922-8.

9. Peralta-Leal A, Rodríguez MI, Oliver FJ. Poly(ADP-ribose)polymerase-1 (PARP-1) in carcinogenesis: potential role of PARP inhibitors in cancer treatment. Clin Transl Oncol. 2008;10:318-23.

10. Sehouli J, Braicu EI, Chekerov R. PARP Inhibitors for Recurrent Ovarian Carcinoma: Current Treatment Options and Future Perspectives. Geburtshilfe Frauenheilkd. 2016;76:164-9.

11. Cortesi L, Rugo HS, Jackisch C. An Overview of PARP Inhibitors for the Treatment of Breast Cancer. Target Oncol. 2021;16:255-82.

12. Lehmann BD, Pietenpol JA. Identification and use of biomarkers in treatment strategies for triple-negative breast cancer subtypes. J Pathol. 2014;232:142-50.

13. Bianchini G, Balko JM, Mayer IA, Sanders ME, Gianni L. Triple-negative breast cancer: challenges and opportunities of a heterogeneous disease. Nat Rev Clin Oncol. 2016;13:674-90.

14. Annunziata CM, Bates SE. PARP inhibitors in BRCA1/BRCA2 germline mutation carriers with ovarian and breast cancer. F1000 Biol Rep. 2010;2:.

Nowak-Markwitz E, dkk. PARP


inhibitors: review of mechanisms of action and BRCA1/2 mutation targeting. Prz Menopauzalny. 2016;15:215-9.

16. Martin-Oliva D, Aguilar-Quesada R, O'valle F, dkk. Inhibition of poly(ADPribose) polymerase modulates tumorrelated gene expression, including hypoxia-inducible factor-1 activation, during skin carcinogenesis. Cancer Res. 2006;66:5744-56.

17. Pouysségur J, Dayan F, Mazure NM. Hypoxia signalling in cancer and approaches to enforce tumour regression. Nature. 2006;441:437-43.

18. Guerrero-Zotano A, Mayer IA, Arteaga CL. PI3K/AKT/mTOR: role in breast cancer progression, drug resistance, and treatment. Cancer Metastasis Rev. 2016;35:515-24.

19. Ortega MA, Fraile-Martínez O, Asúnsolo Á, dkk. Signal Transduction Pathways in Breast Cancer: The Important Role of PI3K/Akt/mTOR. J Oncol. 2020;2020:9258396.

20. Ciriello G, Gatza ML, Beck AH, dkk. Comprehensive Molecular Portraits of Invasive Lobular Breast Cancer. Cell. 2015;163:506-19.

21. Wu X, Sun L, Wang X, dkk. Breast Cancer Invasion and Metastasis by $\mathrm{mPR} \alpha$ Through the PI3K/Akt Signaling Pathway. Pathol Oncol Res. 2016;22:471-6. 